\title{
The plurality of temporal reckoning among the
}

\section{Maya}

La pluralidad de las visiones del tiempo entre los mayas

La pluralité des visions du temps chez les Mayas

\section{William F. Hanks}

\section{(2) OpenEdition}

\section{Journals}

Electronic version

URL: http://journals.openedition.org/jsa/15294

DOI: 10.4000/jsa.15294

ISSN: 1957-7842

\section{Publisher}

Société des américanistes

Electronic reference

William F. Hanks, "The plurality of temporal reckoning among the Maya », Journal de la société des américanistes [Online], Maya times | 2017, Online since 31 December 2017, connection on 01 May 2019. URL : http://journals.openedition.org/jsa/15294; DOI : 10.4000/jsa.15294

This text was automatically generated on 1 May 2019.

(C) Société des Américanistes 


\title{
The plurality of temporal reckoning among the Maya
}

\author{
La pluralidad de las visiones del tiempo entre los mayas \\ La pluralité des visions du temps chez les Mayas
}

William F. Hanks

\section{EDITOR'S NOTE}

Manuscrit reçu en mai 2017, accepté en juillet 2017.

This article is part of the Special issue Measures and textures of time among the Maya: the said, the written, and the lived.

\section{Introduction}

1 The aim of this chapter is not so much to comment on the remarkable array of papers in this issue, but to respond to some of their key themes. The plurality of "measures and textures of time" is my main concern: How do we distinguish different temporal regimes in a single culture, explain their deployment in social action, and determine the hierarchies that relate them to one another? As a short hand, it has often been claimed that Maya time reckoning is "cyclic," meaning that, in a sense, the past recurs on one or another period as defined by the calendar (see Le Guen 2017-this issue). As emerged in discussion during the conference Measures and textures of Time (see introduction to this special issue), it is perhaps more accurate to say that the composite picture of time that encompasses the Mayan calendar and the various ritual and inscriptional practices in which it was embedded, was not circular but spiral in form. ${ }^{1}$ Later periods may align with earlier ones, but they are still later, and the events that fill the durations within any period were historical singularities (see Okoshi Harada 2017-this issue, Ruz 2017-this issue). Epigraphers teach us that the Maya recorded dynastic sequences and events involving named individuals and polities, and this implies a consciousness not only of 
temporal measurement, but of history. The facts that Maya societies were as far as we know always in communication with non-Mayas, and with one another, and that they have now lived through a nearly 500 years history of European colonization and domination both make our object still more complex. For orthogonal to the plurality of time and history lies a plurality of frames of reference.

2 From the perspective of a linguistic anthropologist specialized in colonial and modern Yucatec Maya, I will begin with the temporality of utterance, sometimes called the "deictic field." This is the time in which co-interactants coordinate and orient to one another in a largely linear logic of before/during/after, where the moment of utterance is the Origo or "reference locus" of measurement. This is followed by a series of relatively "natural" phases and cycles, in which, indeed, cyclicity is a major factor: the diurnal cycle, the march of seasons with their signs, and the phases of forest growth-all central to the temporal orientation of Maya daily life and agricultural labor. The timing and rhythm of milpa agriculture governs both bodily movement and ritual performance. Ritual altars, divining crystals (sáastúun) and ritual speech itself project a highly regimented temporality that displays linearity, cyclicity and sedimentation. In the final section, I attempt to derive cyclicity from linearity and spatial distribution, showing in effect that the measures and textures of time for the Maya people I know are the product of several logics, whose articulation is our most important object.

\section{Deictic time}

3 Deictic expressions, such as "here, there, now, then, we, I, you" occur in all human languages, and therefore in all Mayan languages. At the same time, the structuring of the deictic field varies both across languages and over time. Such expressions have the peculiar property that they may be used wherever and whenever Maya speech occurs (and however far back one looks in time), and in reference to any duration or phase of human or non-human time, from the distant past to the imagined future. There is a growing number of studies of deixis, but after a century of modern linguistics, our knowledge of deictic typology is lacking. It is known that these and related expressions are ordered around a basic deictic function, which is to project an individuated referent in relation to a (largely taken for granted) indexical ground, where the Ground is the actuality of utterance in context. Deixis presupposes the actuality of the utterance act (Benveniste's énonciation, Benveniste 1974), which is the first element in the frame of reference.

4 The deictic act itself, whether merely verbal, merely gestural or both in concert, projects a particular relation between the actuality of utterance and another time, which is the space-time object referred to. Every deictic token (singular utterance) therefore implies a deictic relation, if only simultaneity.

e.g. "Here is the pen you are looking for"

$>$ the pen is copresent in the field of utterance (spatio-temporal)

$>$ The person addressed as "you" is copresent with the speaker

But many deictics are specialized in referring directly to time and temporal reference. These are the ones that most concern us. 
In the following remarks, I draw on the work of Bohnemeyer (1998) on the semantics of intervals, and on Desclés (2012) and Monod Becquelin (2012) regarding "thick boundaries" (frontières épaisses). ${ }^{2}$

We can distinguish two broad types of relation between the utterance Origo (Origo énonciatif) and the object of reference, which may be a point or an interval:

Ana-Chronic Past or Future relative to Origo

Syn-Chronic During the Origo

This allows us to imagine something like the following

Fig. 1 - Relations between the utterance Origo and the object of reference.

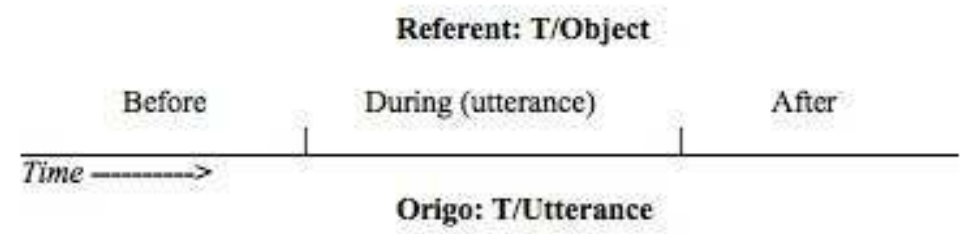

Deictic time, in other words, is a relation between the "now" of utterance (anchor of during) and another time, either earlier or later, before or after.

Every deictic is also susceptible of transposition, a discursive process in which the Origo point of reference is displaced, either to before or to after the actual utterance. This happens for instance in quoted speech, as in "Bob said 'I was here yesterday," where "here, I" refer not to the time in which the quote is issued $\left(\mathrm{T}_{2}\right)$, but to the original time and place at which Bob spoke $\left(\mathrm{T}_{1}\right)$. The reason for this shift in reference is not a semantic change in the meanings of the deictic terms, which remain constant, but rather a pragmatic transposition of the Origo. The result is a pragmatically complex utterance in which two distinct Origos are articulated to one another. In quotation, these would be the respective times at which a first degree utterance was spoken $\left(T_{1}\right)$ and the time at which it is later quoted (and perhaps commented on, $\mathrm{T}_{2}$ ). Notice that, in this example, the past tense of "said" (spoken at $T_{2}$ ) projects the earlier time $\left(T_{1}\right)$, whereas the "yesterday" projects a third referent $\left(\mathrm{T}_{3}\right)$, from the Origo of $\mathrm{T}_{1}$. It is clear that this process is generative is clear when we consider utterances like: "Ben said 'I was here yesterday' when Paul claimed 'I gave my word' when ...." The implication is that through quotation (and other means) multiple Origos may be laminated in a single, temporally complex utterance. The verbs of speaking ('said') mark the distinction between multiple frames. Deixis is functionally specialized for grounding in a frame, but other linguistic resources multiply the frames in which a token may be grounded. For simplicity, I will concentrate here on untransposed examples, but we should recognize that transpositions, which are routine in speech, effectively multiply the frames of temporal reference in play in ordinary utterances.

11 The temporal scope of the present "now" may be narrow or broad, conveying for instance the meaning of "right now" or "nowadays" depending on the context. Such variable scope is also typical of spatial deictics (here, the tip of my nose vs. here, California) and first person plurals (we, me plus one other vs. we, me plus one hundred others). This is another dimension of plurality in temporal reference at the level of meaning 
potentialities, which get determined when instantiated in actual utterances linked to specific communicative contexts.

Consider the following sets of temporally marked deictics in Yucatec Maya, which give a rough indication of the granularity with which time is measured in this sub-system of the language. Temporal deictics are part of the Yucatec Maya multidimensional system of bipartite deictics, each formed with a deictic base associated to a terminal deictic (TD) (see Hanks 1990, 2005).

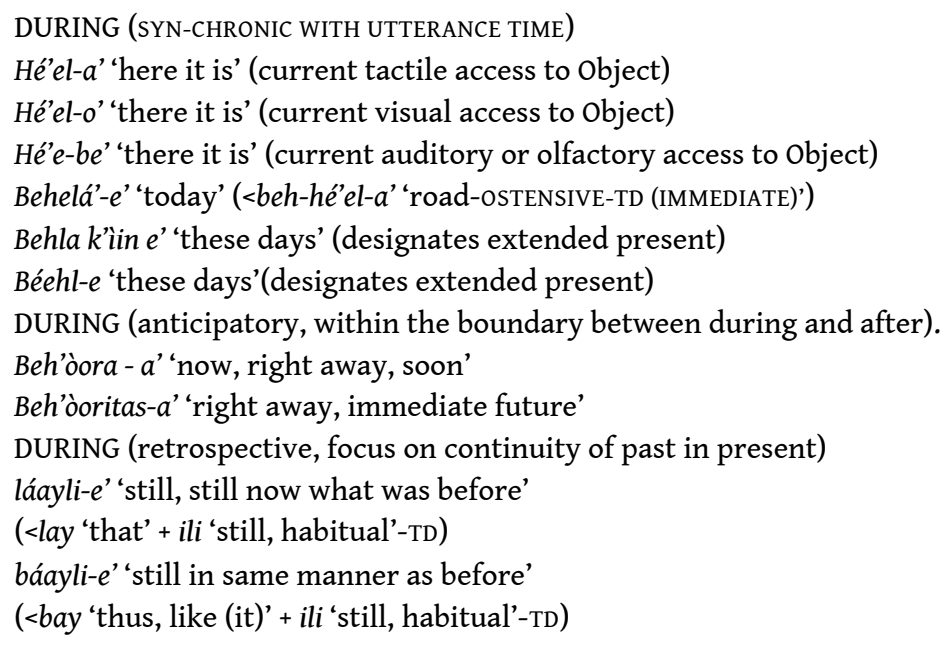

It is worth noting that the preceding expressions, which I have labeled "DURING" imply thick boundaries between the BEFORE and the DURING. We will see below that other forms demonstrate the thickness of the boundary between DURING and AFTER. This is entirely consistent with the quasi-topology proposed by Desclés (2012), Desclés and Guentchéva (2010), and Monod Becquelin (2012).

ISOTEMPORAL (Bohnemeyer 1998): This term is used to designate an interval of time, in the larger temporal frame of the utterance, or in some other temporal frame, typically future. The sameness of time presupposes sameness within an equivalent temporal unit, e.g the diurnal or annual cycle, or the temporal frame of a narrative.

\begin{tabular}{|l|l|}
\hline $\begin{array}{l}\text { walkil-a' } \\
\text { wal-ak-il-a' } \\
\text { root (uncertain origin)-POSIT-POS-IMM }\end{array}$ & 'at this same time, of another day, year, epoch (etc.)' \\
\hline walkil sáamal a' & 'at this time tomorrow' (e.g. noon) \\
\hline walkil a', má'ah timbin & 'at this time, I'm not going (too late or early in day)' \\
\hline $\begin{array}{l}\text { walak-héak-\{a'/o'/e'\} } \\
\text { STEM-PAST-TD }\end{array}$ & 'at this same time of a past day, year, epoch' \\
\hline walak-héak dos 'àanos a' & 'at this time two years ago' \\
\hline té 'àanyo hmáan o', walki ká hbinen xaman o' & 'Last year at this time I went North (to USA)' \\
\hline
\end{tabular}

Of these various phrases, only the isotemporal form appears to (sometimes) presuppose a cyclic delineation of time into repeating units. For the rest, the present of utterance is delineated relative to what preceded (the past) or what may follow (future, anticipatory). 


\begin{tabular}{|c|c|}
\hline \multicolumn{2}{|c|}{ ANTECEDENT (ANACHRONIC RELATIVE TO TIME OF UTTERANCE, RETROSPECTIVE) } \\
\hline Táant-e & $\begin{array}{l}\text { 'what just happened (opposed to taytak, what will happen very soon; immediate past } \\
\text { from perspective of present)' }\end{array}$ \\
\hline Ká'ach-ih & $\begin{array}{l}\text { 'what was, but no longer is' } \\
\text { Focuses on the boundary of the Present-During and the Past, and the contrast/ } \\
\text { difference/discrepancy between both periods }\end{array}$ \\
\hline 'úuch-ih & $\begin{array}{l}\text { A long time ago (grammaticalization < 'uúch 'to occur' + Past tense) } \\
\text { Focuses on the large distance (or discrepancy) between the Present of Utterance and } \\
\text { the earlier Time at which some act was undertaken, viewed from the Present. }\end{array}$ \\
\hline $\begin{array}{l}\text { káach } \\
\text { 'úuchih }\end{array}$ & 'what was in the distance past, but is (explicitly) no more' \\
\hline sáam-eh & '(much) earlier in same day, a while ago' \\
\hline $\begin{array}{l}\text { tol-ak- } \\
\text { héak-o' }\end{array}$ & 'back then' (distant past) < tol o"there' (distant space) + héak 'past' \\
\hline
\end{tabular}

\begin{tabular}{|l|l|}
\hline \multicolumn{2}{|l|}{ SHIFTERS THAT DO NOT FIT INTO DEICTIC PARADIGM } \\
\hline hó'ol-heh, hó'ol-hé-ak & 'yesterday' \\
\hline 'òok-na-héak,'okonheh & 'last night' \\
\hline ká'afhéak & 'the day before yesterday' \\
\hline
\end{tabular}

\begin{tabular}{|c|c|}
\hline \multicolumn{2}{|c|}{ ANTICIPATORY (ANACHRONIC, PROSPECTIVE, IRREALIS) } \\
\hline \multicolumn{2}{|c|}{ See excellent discussion by Valentina Vapnarsky (2017-this issue). } \\
\hline Tayt(-ak) & $\begin{array}{l}\text { almost, in a bit, soon, on the verge of happening } \\
\text { (projects the present into the future) }\end{array}$ \\
\hline Héele' & $\begin{array}{l}\text { modal deictic marking anticipation, what is certain without current } \\
\text { evidence in the Present. }\end{array}$ \\
\hline 'Hé'el-ili-e’ & habituative deictic modal, seems to increase certainty \\
\hline Hée....' & $\begin{array}{l}\text { imminent, what is about to be, projects the imminent future into the } \\
\text { present }\end{array}$ \\
\hline Tàak & $\begin{array}{l}\text { in preparation, anticipated or desired } \\
(<\text { tàal-ak 'come-subjunctive') }\end{array}$ \\
\hline Biín & predictive future (Vapnarsky 2016, 2017-this issue) \\
\hline $\begin{array}{l}\text { Bín a-ká'ah, n-á- } \\
\text { ká'ah }\end{array}$ & imminent, ingressive (you) are going to (lit. go + progressive aspect) \\
\hline Kén, kín, kán, kún & subordinate prospective \\
\hline
\end{tabular}

\begin{tabular}{|l|l|}
\hline \multicolumn{2}{|l|}{ SHIFTERS THAT DO NOT FIT INTO DEICTIC PARADIGM } \\
\hline Sáamal & tomorrow (sáan-samal 'every day') \\
\hline
\end{tabular}


Káa-beh two days after today, the day after tomorrow ( ká'a-ká'a-beh 'every two days')

16 A thorough description of these and similar temporal expressions would necessarily examine the system of Tense, Aspect, Mode (TAM) marking in Yucatec, a topic described in great detail by Bohnemeyer (1998) and by Vapnarsky (1999). What matters most for present purposes is the sheer plurality of forms and frames of reference implied, even limiting ourselves to a constrained set of lexical items.

If we think of deictic time as 'ordinary' time, then speakers ordinarily formulate the present not as a stand-alone given, but in relatively complex relation to what preceded and what is to follow the present. The boundaries of the present are thick, on both sides, and they depend, in any actual use of deixis, on an interactively established frame of reference, which I have called the Origo.

The basic feature of deictic time is that it establishes a relation, a 'repérage' "locating operation" (Desclés 1987; Desclés and Guentchéva 2012) between the Origo (Ground), and the time referred to, the referent (Figure).

Because humans are not merely chronometers, but experientially complex social beings, this relation also implicates desire, anticipation, epistemic stance, obligation, memory (recall) and the relative symmetry/asymmetry of participant knowledge. What we see in deictic time is the intersection of time, space and cognitive access. This is no less true of the Mayan languages than of English, French or Spanish.

\section{The diurnal cycle}

We have seen that the daily round of the sun and human activities is a background feature of ordinary time, referred to by the stages of the day, and largely presupposed by terms like walkila 'at this time of day (in some other day).' The diurnal cycle mostly obeys the movement of the sun, and is therefore cyclic.

\begin{tabular}{|l|l|l|}
\hline Interval & Gloss & Typical activity \\
\hline tusuhuy 'áak'ab & midnight 'holy-hour of night' & $\begin{array}{l}\text { wenel 'sleep' } \\
\text { wayak' 'dream' }\end{array}$ \\
\hline 'áak'ab & night, darkness & variable activities \\
\hline kupíikil k'ìin & the sun appears & ahal 'awaken' \\
\hline kuhóok'ol k'ìin & the sun comes out & $\begin{array}{l}\text { lik'il 'get up' } \\
\text { 'uk'ul 'break fast/drink' }\end{array}$ \\
\hline há'atskab & 'strike-earth (sunrise) & head off to work \\
\hline kusáastal & morning ('it lightens') & meyah 'work' \\
\hline chun k'ìin & trunk of sun (strong sun late morning) & meyah 'work' \\
\hline bulu' k'ìin & inundating sun (early afternoon 12h-16h) & $\begin{array}{l}\text { he'lel 'rest' } \\
\text { hanal eat }\end{array}$ \\
\hline táan k'ìin, túulis k'ìin & full sun &
\end{tabular}




\begin{tabular}{|l|l|l|}
\hline 'òohk'ìn & dusk ('enter sun') & meyah (light) 'work' \\
\hline 'éek'samé'en & dark, black of night & $\begin{array}{l}\text { ichkil 'bathe' } \\
\text { 'uk'ul 'drink' }\end{array}$ \\
\hline 'áak'ab & night & $\begin{array}{l}\text { tsikbal 'converse' } \\
\text { wenel 'sleep' }\end{array}$ \\
\hline
\end{tabular}

21 The indexical walkila' can anchor in any phase of diurnal cycle, referring to the same phase in another cycle. E.g. if spoken at dusk, walkila' refers to the same interval as 'òoh'in 'dusk'.

The alternation between 'áak'ab 'night' et k'ìn 'sun, day is therefore basic to the meaning of the foregoing expressions. This alternation is indeed cyclic because the planetary movements are cyclic, and the expressions key into intervals within a repeating diurnal cycle. In this cyclic progression, 'áak'ab 'night' would seem to be the beginning of the cycle, since 'aak' indicates 'young, flexible, unripe, moist.' These standard terms designating phases of the day organize a great deal of information, including the movement of the sun, light $\neq$ darkness, dry $\neq$ moist, hot $\neq$ cold, labor (creating body heat) $\neq$ rest, place of activity (hammock, inside home, in domestic space, at worksite, etc.). Cyclicity at this level is indeed a powerful schema for organizing knowledge.

\section{The agricultural cycle}

The alternation of seasons implies climatic variation; and is by default cyclic, including epicycles within seasons. In the Sierra region of Yucatan, they are roughly as shown below. This is strictly heuristic but will suffice to make the point that seasonal variation (a) is relatively regular from year to year, and that (b) within any year, different seasons call for, or correlate with, different kinds of labor. People do many forms of labor, but the work calendar for a kòolnal 'campesino, milpero' (farmer of fields of corn, beans, or squash) is anchored in the care of their fields, crops and harvests. I have noted in the following table relative hotness, dryness, kind of work being done, and where appropriate some of the ritual calendar, which further amplifies the cyclicity of the year.

\begin{tabular}{|l|l|}
\hline September & $\begin{array}{l}\text { Occasional rains, cooling progressively } \\
\text { work: kòol 'fell forest' in nukuch k'áax 'old woods' Pàak 'weeding' }\end{array}$ \\
\hline October & $\begin{array}{l}\text { work: wàats' break/bend corn stalks (from previous cycle) to protect mature } \\
\text { ears from birds and moisture kòol 'fell forest' in yáax k'àax 'young growth' and } \\
\text { ká'ana húup che' 'tall brush' } \\
\text { ritual: wàahil kòol 'thanksgiving' (variable timing) }\end{array}$ \\
\hline $\begin{array}{l}\text { November- } \\
\text { December }\end{array}$ & Increasing cold, felling continues \\
\hline January & $\begin{array}{l}\text { Kéel 'cold' } \\
\text { work: miscellaneous, finish preparing fields to dry for burning }\end{array}$ \\
\hline February & Transition to early yáaxk'ìin 'great sun', hot season \\
\hline
\end{tabular}




\begin{tabular}{|l|l|}
\hline March-April & $\begin{array}{l}\text { Transition to 'maximum heat' chokow k'ìin 'hot sun' tikin 'dry,' túulis k'ìin 'whole } \\
\text { sun' } \\
\text { work: harvest of corn from previous cycle (hóoch) } \\
\text { ritual: wàahil kòol 'the loaves of the field; thanksgiving' }\end{array}$ \\
\hline May & $\begin{array}{l}\text { Yáax k'ìin peak heat and dryness, strong hot winds Kup 'ìk' 'suffocating' chokow } \\
\text { lúum 'hot earth' } \\
\text { work: tóok 'burn' the milpa, lots of smoke in the air, harvest and process achiote } \\
\text { (k'uxub) } \\
\text { ritual: tup k'áak' 'extinguish fire' }\end{array}$ \\
\hline June & $\begin{array}{l}\text { Chokow k'ìin 'hot sun;' onset of há'ahal 'rainy season' síiskuná'an lú'um 'earth is } \\
\text { cooled' (by rain) kusístal 'weather turns (slightly) cooler and wetter' } \\
\text { work: pak'al 'plant (the milpa)' }\end{array}$ \\
\hline $\begin{array}{l}\text { Jály-Augul 'rainy' and lùuk' 'mud (abundant)' Kanikula 'short hot and dry spell } \\
\text { (imperils crops and causes sickness)' (mid August) } \\
\text { work: páak 'weeding,' pak'ik xnuknal 'plant corn' (traditional, short-cycle } \\
\text { variety); lean season with very low food supplies } \\
\text { ritual: ch'áa chak 'rain ceremony' Primisyas 'first-fruit' rites making vow, } \\
\text { petition, creating a t'íin 'obligation' to perform wàahil kòol after the harvest }\end{array}$ \\
\hline
\end{tabular}

The transitions and peak periods of the seasons are associated with various natural signs. Of the onset of peak heat of Yaáxkiin it is said that Kuwá'ak'al uyich xtàak'inche 'the fruit of Xtakin tree burst (in heat)'. On especially hot years, the leaves of há'abin tree rattle in the wind, and the sound is likened to rattlesnakes. It is also at this time that the universally feared xùulab ground wasps swarm in forest. These are extremely aggressive and potentially deadly. The púuhwih bird sings at this time also. With the arrival of rains, the chan siinik 'small ants' come out, especially swarms of flying ants. While they do not sting, the flying ants may effectively swarm and fill the air. The coming xaman ka'an 'northerlies' the cold storms of October is announced by the singing of the kòos bird. At any time of the year, ch'om 'vultures' may be taken as an augury (tomoh chi') of imminent of death.

Traditional Maya agricultural practices are based on swidden agriculture, in which forest is felled and chopped, dried, burned and planted each year for cycles of variable length, roughly three years in production, followed by fallow of a duration that depends upon the state of the field. In the terms used to describe growth phases, the current state of the vegetation as well as its timing in the swidden cycle are encoded, making this terminology very rich in implications for both temporal measurement and the kind of labor implied to work the land in its current state, the tools required, and so forth.

\section{Life cycle of the forest}

\begin{tabular}{|l|l|}
\hline labá'an k'áax & rotting forest (oldest) \\
\hline nukuch k'áax & $\begin{array}{l}\text { 'old growth forest } 25+\text { years, when felled and planted this becomes tumben kòol } \\
\text { 'new milpa' }\end{array}$ \\
\hline & \\
\hline yáax k'áax & 'great forest $15-25$ years, becomes xkáa kòol 'second milpa' \\
\hline
\end{tabular}




\begin{tabular}{|l|l|}
\hline & \\
\hline táankelem káax & 'young forest 4-5 years, becomes kòol 'milpa' \\
\hline & \\
\hline hu'u'che' & 'little trees' 2-3 years, becomes kòol 'milpa' \\
\hline pok che' & 'growth after one year fallow, becomes kòol 'milpa' \\
\hline & \\
\hline sak'ab & 'corn plant(s)' \\
\hline $\begin{array}{l}\text { ch'akbé'en } \\
\text { sak'ab }\end{array}$ & last year's dead stalks, first cycle tumben kòol 'new milpa' \\
\hline (or kanyada sak'ab) \\
\hline
\end{tabular}

Each of these expressions may be used in reference to the place. In such usage, temporal measurement is embedded in the spatial description of the cultivated land, as seen in the following examples (see also Hanks 1990, p. 359-360):

Kimbin tin xkáakòol

'I'm going to my second milpa'

(to my field in its second year after having been felled from great forest)

Behela tinmeyah tin ch'akbéen sak'abe'

'Today I'm working in my milpa'

(which is in its first year of fallow, having been cut from old growth forest)

\section{The phases of milpa work (in order, from first to last)}

\begin{tabular}{|l|l|}
\hline p'ìis & 'the measure of the perimeter' \\
\hline tsol xú'uk' & 'put the perimeter markers in order' \\
\hline hóol ch'ak & 'fell the forest in a perimeter corridor' \\
\hline kòol & 'fell the interior of the space destined to be a field' \\
\hline tíhil & 'to dry (duration depends upon age of felled vegetation) \\
\hline tóok & 'burn' \\
\hline pak'al & 'plant' \\
\hline pàak & 'weed' \\
\hline wàats' & 'bend the corn stalks with mature fruit' (to protect from birds and moisture) \\
\hline hóoch & harvest the dried corn on its cobs \\
\hline
\end{tabular}


Once harvested, the corn ears are stored in their husks, open end downward, in granaries. If the field is still in production, the cycle restarts with felling. If necessary, the field is left fallow after the harvest.

During the first two steps, before the field is felled, it is k'áax 'forest'. Once it has been felled, the field is called tá'ache' 'trees in pieces'. Once burned, hence in ashes, it is called 'éele kòol 'burned milpa'. As soon as the seeds are planted, the milpa is 'in nal 'my corn (living).'

Work (meyah), the labor of milpa, is the operator that transforms the raw material of nature into food in a regular sequence of phases. This transformation implies the coordination of multiple cycles: the seasons, the multi-year growth cycle of vegetation (which depends upon the type of vegetation), the swidden cycle (roughly 3 years, depending upon soil quality), the annual ritual cycle, the diurnal cycle of labor and rest, all adjustable according to actual present circumstances. This is rich temporality, codefined by multiple cycles.

30 This picture becomes more elaborate if we include the seasonal work of tending, irrigating and harvesting orchards, the many fruit bearing trees, and other irrigated crops. The difference of course is that the unirrigated milpa is the source of corn, also called with the loan word gracia, and corn production is at the heart of the ritual calendar. Corn is offered in several forms in every major type of ritual ceremony. Even though the people with whom I worked produced and sold commercial quantities of citrus, no one ever offered orange juice to the lords of the sky, forests or fields.

\section{Domestic space and reproduction}

31 In my fieldwork I have spent time in dozens of households, and observed that virtually all of them were in a seemingly continuous state of construction, repair and work of various kinds. Infrastructure such as running water, electricity and plumbing (all but nonexistent in the rural zone outside the towns), and appliances such as refrigerators and stoves, all change the temporal rhythm of life around the household, and have implications for labor. In gross terms, the domestic sphere responds to work rhythms governed by gender, season and by the diurnal cycle. According to the season, people may shift their sleep place for cool or warmth, and many Maya people whom I know have more than one residence, among which they move temporarily.

But the domestic sphere is especially embedded in the generational structure of its inhabitants. This can imply several generations through the male line. In my experience, one, two or three generations are the norm, depending upon the age of the founding husband-wife and the scale of the domestic space. A very senior couple may co-occupy an extended household with their sons, who have their own wives and children. Within multi-generational households, each nuclear family is economically independent, although men often work together, while also maintaining their separate fields, and potentially pursuing other occupations as well (day labor, truck driver, seasonal work). Like the milpa, the domestic space is in multiple time streams. 


\section{Aspects of ritual time: The temporal scope of tíich'k'àak' 'divination'}

33 I have mentioned the ritual calendar associated with agriculture, but it is important to see that this is only one dimension of Maya ritual practice. Hmèen 'shaman(s)' also perform therapeutic rituals (ts'àak) and diagnosis using sáastúun crystals (tiích'káak'). They do this all year round and on any day of the week or month. Here the relation to temporal cycles or orientations is less obvious, but still in play. In tích'k'áak' diagnosis/ divination, the sáastúun 'crystals' can shed light on the past (before the time of performance) and the present (during the time of performance), but they say nothing of the future (after the time of performance), except by extrapolation from past or present. The shaman hok'sik swèrte 'tells the fortune' (from the Spanish expression sacar la suerte) of the patient, but cannot see what will occur. The signs in the crystals never stand for future events. By contrast, objects and events in the past or the present may be invisible to the naked eye, but are rendered visible in the light of the crystals. There is therefore a covert classification of time in the practice of divination: Past and present are accessible, whereas the future is not.

\section{Altars as chronometers in ritual time}

Yucatec ritual altars are of several kinds, and both they and the offerings and objects placed on them have chronometric dimensions. The ch'áa cháak rain ceremony altar is an elaborate, quadripartite formation of four altars arranged as the sides of a large rectangle with open ground in the middle and an altar on each side. The main altar faces East and is the largest, while the other three face South, West and North. They are each rectangular, constructed of newly cut poles lashed to a frame with four raw-cut legs, with all of the joinings bound by vine. The four altars are in turn bound to one another by connecting vines, and the whole is adorned on the top by vine arches which will be covered in freshcut fruit-bearing corn stalks. The pit oven in which sacrificial loaves are baked is always placed to the West of the altar. Moreover, on any single altar within the complex, offerings are placed according to a template that iconically replicates the cardinal directional locations of the spirits (yuntsil) to whom the offerings are presented. What is invisible in the spatial arrangement of offerings is the temporal fact that they are placed and offered in a specific sequence. Moreover, like all major rites, the rain ceremony has two or more altar settings. The first is a liquid phase with gourds containing sakab 'corn gruel' and balche' (mildly alcoholic beverage of fermented balche' bark). It is only in the second phase that loaves and roasted fowl will be offered. The material and spatial qualities of the altars and offerings are permeated by the temporal texture of the offertory process.

As pointed out above, the timing of the rain ceremony is embedded in the agricultural and seasonal cycles of the year. It is usually done in mid-August, during a time known as kanikula, when rains are known to pause, and the growing plants are very vulnerable to the dryness. The quadripartite structure is abandoned after the rain ceremony, and simply left to láabal 'rot' in the weather until the next performance in a coming year, 
when it will be repaired or replaced under the supervision of the performing shaman. Thus, the ch'áa cháak altar itself has a sort of life cycle.

There are two other collective rites with major altars, albeit not quadripartite ones. These are the wàahil kòol 'breads of (the) field, thanksgiving', and the hets' lu' um 'settle, calm earth', an exorcism of domestic space (or of a corral or a water source) (Hanks: 345 seq., $377 \mathrm{seq}$.). In both cases, the altar at which the ceremony is performed is the domestic altar of its individual sponsor. In households with more than one nuclear family, each family will have its own home and family altar. This altar is moved from inside the home out into the courtyard or adjacent field, where the ceremony takes place. Domestic altars are four legged machined wooden tables, typically made of cedar. The ch'aa cháak rain ceremony altar is made of fresh cut unskinned poles lashed with 'áanikab vines-not the kind of table that is the typical domestic altar. Thus, whereas the rain ceremony is jointly sponsored by those men who work milpa fields in a single area, thanksgiving and space cleansing are sponsored by the co-residents in the same extended household.

The thanksgiving ceremony (wàahil kòol), is performed after a harvest, and I have participated in ones held in both October and March. By contrast the hets' lúum is entirely unrelated to agriculture, and linked rather to the exorcist process of cleansing a domestic space that has been infected by malevolent spirits. Diagnostic indicators of the need for this treatment are, for instance, unexplained death among domestic animals, strange sounds and frights coming from the yard, recurrent, inexplicable malady among residents. This ceremony, is part of a small set, including also hets' kóoral (corral, where animals are kept), and hets' ch'éen 'well (water well).' All of these remove malignant spirits from non-agricultural spaces frequented by humans or their livestock. The timing of hets' performances is governed not by cyclicity of any kind, but by the empirical need to make a therapeutic intervention. A key part of this class of performances is that special offerings are buried in the ground at the corners and at the middle of the domestic space being treated. These offerings include chúuk 'charcoal' with which Ah Kiin spirits record the performance in a heavenly ledger. Other offerings are put there in order to post guardian spirits who assure the integrity of the protective perimeter, and so the wellbeing of the inner space, in the months and years to come. Occasional small scale offerings by the household to the guardian spirits will help maintain the protective effect the hets' ceremony going forward, and are highly recommended.

The use of the domestic altar for these rites begins and ends with the ceremony itself, after which the table is cleaned off and brought back into the home. Inside the house (nah ), it will function in the dual capacity of the family altar with one or more santos (crucifixes, saint images or effigies), a votive candle and flowers, and at the same time, an ordinary table, on which sundry objects are kept. When not in use during a rite, it is integrated into daily life, and one can find hats, packages, cigarettes, toilet paper, tools etc. upon it. In other words, in the performative frame of a ceremony it is sacralized, but in everyday life it is in no way set apart.

During the hets' lúum ceremony, the domestic santo of the sponsor is also bought out to the yard, and placed on the East face of the altar, where it stays throughout the entire ceremony (which can run the better part of a day). This means that when the spirits are lowered to the gifts, they come into co-presence with the family santo, and this has a sanctifying effect on the santo, imbuing it with spirit (see "power objects" below). When the santo has been inherited, as is often the case, it also brings with it the inter- 
generational temporality of inheritance. Here we have another dense layering of time and temporal measurement.

\section{Power objects on the altar}

The objects on the altar, especially the santos and any offerings, take on peculiar properties during the sacralized time of performance. The material santo sits placidly on or above the domestic altar, and is often adorned with flowers and a votive candle (canonically tended by the senior female of the house). In daily life, the santo is merely a background part of the house, rarely the object of attention, comment or address. Asked why they had santos in their home at all, most people I spoke with said without hesitation that the santo is a reminder (kuk'áasik tech 'it reminds you'), that is, it is a sign that reminds you of God and your dependency on him. By contrast, in performance time, the same material object is the explicit focus of attention, and functions as a counterpart of the yuntsil 'lords, also called' 'iik 'spirits, winds, breath'. These spirits are lowered to the altar, and therefore to the material santo, during performance. Called payal chi 'summoning speech', all of the core genres of shamanic performance have in common that they lower ('éensik 'cause to descend') spirits from their places in the heavens down to the immediate field of the altar. The material santos play an important role in this lowering.

41 The upshot of these remarks is that a basic shift in footing takes place in performance, and it alters the semiotic properties of the material santos on the altar. What in ordinary time is a backgrounded symbolic representation that stands for spirit as its object, and serves as a reminder of an existential dependency, becomes something much more dynamic in the frame of performance. Quickened by prayer and undivided pious attention, the material object ceases to be a standard symbol, and becomes a sort of magnet to which spirit addressees are drawn by speech. The candles required on the performative altar serve to light the way. In collective ceremonies performed outdoors, incense perfumes the way. Once lowered, the spirits partake of the offerings right there on the altar, consummating the gift in co-presence with the shaman, patient and onlookers.

An analogous shift occurs to the divining crystals. During ordinary time, the crystals rest in their holy water in a gourd left in an out of the way place on the altar. During the tiich'k'áak' 'illumination' (lit. 'hand_over-fire') performance, they are quickened by prayer. Once quickened, they display signs read as responses expressed by spirits, to questions spoken by the shaman. The crystals are a communication technology whose effectiveness depends upon their being "turned on" by a specific kind of prayer (see also Hanks 2006).

In this process, material santos and the crystals become what I will call "power objects." They all share two distinctive properties.

First, they accumulate the pious intentions of the person who uses them, through a process of sedimentation. When one prays before a santo, or uses divining crystals, the faith and will to pray of the person stays in the object, imbuing it with a relatively durable quality. The more it is used, the more of this quality it accumulates. A well used cross or other santo holds within itself the history of its participation in the act of prayer, including the accumulated pious intentions of the praying human, and the co-presence 
with divinities brought about by prayer. Power objects become powerful because they embody a history of ritual time.

The second property is closely related to the first. In ordinary time, these apparently inert material objects are signs in the sense that they stand for the divine, as a cross might stand for Jesus. But they are a special sort of sign, capable of activation through prayer. During prayer, they are rendered live and, no longer merely standing for the divinities, they become attractors - helping to draw the spirits from their places down to the altar on which the enlivened santo (or the intentionally invested offering) is placed. During ritual performance, the hmèen 'shaman' is surrounded by the spirits whom his words move, or as Don Chabo, a hmèen from Oxkutscab, always said, he "lowers them" to the altar. In exorcism, these spirits once lowered are described as a "wall of fire," protecting the participants from the evil about to be cast out of the body. The spirit guardians usher the intrusive spirit away, banishing it to a cave or chultúun far off in the forest. Whereas intentionality is accumulated and endures or accrues in the object throughout its life, the attractive power to bring the spirits to the altar is most intense in performance-and it depends upon which spirits are named in the words of performance. In short, the normal intentionality of a sign standing for an object is reversed, and the power object draws to itself the spirit it seems to represent. This process is clearly similar to indexical transposition, in which a distant individual or object is made present in the context of utterance (Hanks 2005).

This dynamic reversal from projection to attraction places a premium on the function of ritual speech in bringing the santo to life as an attractor. The conversion is a highly technical part of shamanic practice which consists in knowing which spirits to name (thereby lower), and in what order to name them (e.g. allies before enemies) (Hanks 1984). It is in this threshold domain that we find the most dramatic examples of cyclicity in the expressive culture of the contemporary society. Indeed the ordering principles on spirit nomination are apparently very ancient and are described with language similar to that of the historical cycles of the Mayan calendar. The act of ordering is expressed in the semantically rich Maya verb tsol 'count, place in order, recount, explain, translate.' In the calendar, this yields the Tzolk'iin 'day count', formerly used to refer to the 260 days Prehispanic calendar. In modern shamanism, it is the operator whereby a santo becomes an attractor, as the spirits are tsolá'an 'put in order' in prayer. The exact same term is used for the spatial process of placing the offerings on the altar, which become a miniature icon of the arrangement of their spirit addressees in cosmological space.

\section{Ritual discourse, the paradigm case of cyclicity}

Ritual discourse is governed by three constraints, grounded in the characteristics of the spirits whom it lowers to the altar, and in the linearity of the performative utterance. The conversion from spatial distribution to temporal sequence of invocation is the source of the most fully realized cyclicity I know of, beyond the pre-Columbian calendar. Indeed, I will argue that it is the key to cyclicity in Yucatec ritual discourse. 


\section{Four principles of spirit identity}

The spirits, lords, saints and other forces set in motion by shamanic performance have certain basic properties which constrain when and why one invokes them. There are many scores of spirits nominated in payal chi' and they differ in numerous ways, but at the heart of the system lie four principles that apply systematically to all of them.

1) The naming principle, according to which any invocable spirit has a proper name, which is the term by which it or they are called to the altar.

2) The cardinal principle, according to which every divinity "sits" (yàan uk'uh 'it has its temple') in exactly one cardinal sector (four directions plus the center, five in total). Each direction is also associated with a color: East (Red), North (White), West (Black), South (Yellow), Center (Grue). This partitioning of cardinal space is familiar to any Mayanist, and is found in the tzolk'iin calendar portions of the post classic codices (although often lacking the Center cardinal).

51 3) The vertical principle, which divides vertical space into a series of nine levels above the earth, beneath Heaven, plus the surface of the earth and its atmosphere-yóok'ol kàab 'the above earth'-plus the subterranean world that includes caves and the underground passages of the 'nukuch sáayabóob 'great underground rivers,' of which there are many in Yucatan (this is the hydrology of a limestone peninsula). Still lower, Hell and its fires burn and beneath them lays the Moon. The cardinal planes are conceived as tilted, such that Top is East (=Sun), and bottom is West (=Moon). The shaman at his altar is facing up, East and the divine. Gossen (1974) described more or less the same schema among contemporary Tzotzil people.

52 4) The agency principle, which governs the spheres in which any spirit type operates in the world. For instance, the Chac spirits engage in rain distribution, whereas Jaguar spirits are guardians of the yóok'ol kab "above earth", that is, the surface and immediate atmosphere of earth. They also participate in tiich'k'áak' divination (see above). As a consequence of this principle, the objectives of a given ritual performance will determine which spirits are relevant and need to be engaged, and which ones remain in the background, sitting in their heavenly k'uh 'temple.'

Taken together these four principles assign values to individual spirits and classes, yielding a precise classification of spirits. The name, the cardinal value, the vertical value and the agent role provide a bundle of information that is critical to performance of payal chi'.

\section{From spatial distribution to temporal sequence}

54 As we know since Saussure, speech, conceived as the flow of sounds, is linear by nature: it unfolds in time and sequences. This is no less true of ritual discourse than of ordinary utterances. Therefore if we are to invoke spirits or divinities by name according to their locations in cosmological space, we must transform their spatial distribution into a sequence in the linear time of ritual utterance. In principle, the order of cardinal sectors and levels could be random, with spirits appearing in any possible sequence. In fact, the order of naming is tightly constrained. 
ctraints may be stated as two additional principles (which I have identified in therapeutic ritual Santiguar (Hanks 1984), but which are in force in other genres as well).

1. In order to 'éensik 'lower' divinities from their cosmological places to the altar space, at the outset of a rite, a) one cites the divinities at any level in the cardinal order ENWSC, that is, in counter-clockwise, beginning in the East, and ending in the Center, and b) one cites lower divinities before higher ones.

2. In order to sutik 'send (them) back' to their cosmological places ( $k$ 'uh) at the ending portion of the rite, a) one does the inverse, still beginning in the East, but going clockwise ESWNC, and $b$ ) one cites lower divinities, before higher ones.

3. In both lowering and returning spirits, one cites those of a single level in a continuous series, without interpolating spirits from other levels, and $1 \mathrm{~b}$ and $2 \mathrm{~b}$ can be collapsed into the rule that for any pair of names, Low precedes High.

Notice that both orders start in the East, end in the Center, and maintain the West in medial position; this is invariant. It is only the reversal of $\mathrm{N}$ and $\mathrm{S}$ that distinguishes clockwise from counter-clockwise orders. From the embodied perspective of the praying shaman, the difference is whether one goes to the left $(E>N)$ or to the right $(E>S)$. In both orders, according to (3), lower spirits are invariantly named before higher ones.

The result of combining these several factors is that the relentless cyclicity of payal chi recitation is actually of two kinds: the horizontal cyclicity of cardinal directions at a given level, and the vertical spiral caused by combining cyclicity with the verticality of low before high. These principles are normative in the sense that Don Chabo, was able to formulate them as rules of practice: "you cite them in this order: ..." He justified them by the need to create a beel 'road' for the divinities to descend to the altar in an orderly fashion. Candles and incense on the altar adorn the road to the altar.

nowledge represented by the cosmogram summarized above is therefore essential to understanding why spirit names are produced in certain sequential orders, but not in others. The period of the cardinal cycles and their ramification over different vertical levels produce a special quality of time and space in ritual performance. Starting from separation, the spirits are called and lowered into co-presence with the shaman, the altar, and the patient or beneficiary of the performance. After the appropriate duration of copresence, they are sent back to their temples in the skies.

There are multiple other temporal measures that impart qualia to the ritual time of performance. The chanting is done in breath groups, so that closely related spirits are named in the same breath. This introduces body time and can imply demanding breath control (Hanks 1984). The event itself is part of a historical sequence, as we saw with the rain, the thanksgiving and hets' ceremonies. There are still other dimensions of temporal measurement and organization, but this will suffice to make my point: cyclicity as we usually think of it is not the starting point, the by-product of converting spatial arrangement into temporal sequence. Because the space is co-organized by cardinal direction and vertical trajectory, and because sequence is an icon of location, the inevitable result is cycles embedded in a spiral shaped progression. Cyclicity, we might say, is the product of dividing spatial distribution by temporal sequence.

Journal de la société des américanistes, Maya times | 2017 


\section{Conclusion}

60 We have briefly sketched several domains of practice among Yucatec Maya people, in which timing, rhythm, sequence and duration are saliently in play. An ethnology of the measures and textures of time must start from the recognition that there are multiple temporal regimes at play in any Maya society. What seems most interesting is not to focus solely on one or another temporal regime, but to investigate the ways they combine and articulate in different kinds and genres of practice. In ordinary time, we started with deixis, surely one of the most delicate systems of spatiotemporal orientation. In this sphere, there is very little cyclicity, but a far-flung system of repérage between the focal objects, events and times referred to, and the backgrounded utterance frame in which the reference is made. For any deictic, the copresence between utterance frame (now) and focal referent implies synchronization, but temporal deictics also permit anachronic reference to other times and places. The key logic here is the relational one binding the background frame of utterance to foreground frame of reference in the deictic act.

Ordinary time also encompasses the diurnal cycle, seasonal variation, the agricultural cycle (the year and the multi-year), and the domestic cycle (generational). All of these provide repeating sequences of periods during which human activity and labor is performed, so that human practices synchronize to natural cycles. You simply do different kinds of labor in August from what you do in April. In what I have called ritual time, we find elements of both deictic repérage, dependent upon the field of co-presence, and synchronization, dependent upon co-timing the act of deictic reference with the independently defined spaces and times to which it refers. We also find in ritual performance a profusion of temporal processes including sedimentation, the sequential projection of space into time (the cardinal principle, and the vertical principle), the alternating status of santos in ordinary vs. ritual time, and the variable temporal intervals between successive performances of a given genre.

Ritual time is so richly structured that it is legitimate to think of the payal chi' genres as a system for producing time itself. This is not a time machine in the sense of permitting the shaman to leave his phenomenal co-present in order to enter another time-space-the shaman in performance stays put at the altar. Rather, as I emphasized above, it is a matter of synchronizing the phenomenal present to the time-space of the yuntsil, 'iik', spirits at all nine of the above-world levels (from earth to the highest sky) and all five of the cardinals. This is done by lowering spirits into the field of copresence at the altar. The spirits travel to the shaman, not the other way around. While certain kinds of payal chi' can be done without a santo or an altar, these material elements are necessary for all of the significant genres. They are an important part of what makes the altar a very powerful chronometer - it makes time in co-presence, stores time as sedimentation, embeds itself in one or more historical series.

At the heart of these effects lies the utterance (énonciation) of payal chi', and the flow of co-speech gestures that are joined to it over the process of performance. It is, after all, payal chi' that animates the material santo, activates its capacity to attract the spirits down to its locus, and sediments intentionality in it, imbuing it with moral qualia. As we saw in some detail, in payal chi' performance, the sequential order of spirit nomination is highly constrained, and this means that the order in which spirits descend to the altar is equally constrained. The laws of cardinal and vertical sequence convert space into time, 
and the ontological separation of the earth from the heavens into co-presence of the divine on the earth. The same laws produce the most elaborate forms of cyclicity I am aware of in the modern culture. If we compare the cycles and spirals of ritual time with the natural cyclicity of the diurnal cycle, the seasons, the yearly agricultural cycle, and the inter-year swidden cycle, we see that they all share a fundamental feature. This feature is iconicity, the reproduction in human action and labor of the order of nature or the spirits who govern it. The transmutation of spatial arrangement into temporal sequence in ritual, and the synchronizing of labor to naturaleza (a loan word from Spanish sometimes used in Maya) 'nature' (the seasons, winds, rains, temperature, diurnal cycle) are at the root of the same process.

There is a semantically rich Maya term for this iconizing process. The term is tsol (tzol in Colonial spelling), a polyvalent root meaning roughly 'place in order, or in an ordered arrangement.' A coherent sequence of words 'explains' something, a narrative 'tells' a story, the flow of discourse in payal chi' 'orders' spirits, the shaman lays out the offerings in a determinate order on the altar-all of these are tsolá'an 'ordered'.

Tsol is the operator that produces iconicity in the act of arranging objects (days, offerings, words) according to a schema that lies elsewhere in historical or cosmic time and space. Some well established domains taken from the Colonial Yucatec lexicon in which tsol is the core concept are shown below.

\begin{tabular}{|l|l|}
\hline tzol k'ìn & 'order day,' standard name of the 260 day calendar \\
\hline tzolan beh & 'ordered road,' standard term for 'history' \\
\hline tzol pictun & 'order boundary stones,' standard for land survey \\
\hline tzolic mèesa & 'order table,' standard for placing of offerings on altar \\
\hline tzol than & 'recount language,' standard for 'translate, interpret' \\
\hline tzol & 'explain, tell in coherent order' \\
\hline
\end{tabular}

In each of these examples, tzol indicates the transmutation of objects or events in space into a linear sequence of units (days, events, boundary markers, offerings on the altar, ideas in one language, expressed in another). Each domain has its own organization: the calendar defines a year of 13 months, each composed of an ordered series of 20 days. The land survey is defined as an ordered sequence of boundary stones which together define the perimeter of the surveyed space. The arrangement of offerings on the altar is iconic to the cosmological sites of the spirits to whom they are devoted. Cross-language translation renders meanings from one language into the (syntactic) order of another language. Explanation and interpretation both render ideas in a coherent order. Of these, the calendar, the land survey and the ritual performance are the prototypes of cyclic space-time in Yucatec Maya. Like iconicity, tzol is focused on reproduction-the sign reproduces certain features of what it stands for. Tsol lies at the heart of Maya time/space reckoning.

67 There is another modality however, which applies equally well to most of the domains in which tsol appears. This modality is not iconic or reproductive, but productive; it alters reality. The Maya term meyah (< mèen-yah 'make-pain') is the standard term for work of any kind, including heavy labor, desk work, or performing any task requiring effort. All of 
what I described as labor in agriculture is known as meyah. In the context of shamanic practice, ritual performance is itself a form of meyah, as is diagnosis and curing. Don Chabo always referred to his practice globally as le meyaho' 'the work.' Even the divinities who descend to the altar to intervene in human affairs are 'working.' The work of ordering is the making of time.

\section{BIBLIOGRAPHY}

\section{BENVENISTE Emile}

1974 “L'appareil formel de l'énonciation", Problèmes de Linguistique Générale, 2, éditions Gallimard, Paris, p. 79-88.

\section{BOHNEMEYER Jürgen}

1998 Time Relations in Discourse: Evidence from a Comparative Approach to Yukatek Maya, Ph.D., Katholieke Universteit Brabant.

DESCLÉs Jean-Pierre

1987 “Réseaux sémantiques : la nature logique et linguistique des relateurs”, Langages, 87, p. 57-78.

2012 "Du trimorphe aux frontières quasi topologiques", Ateliers d'anthropologie [en ligne], http:// ateliers.revues.org/9172; DOI : 10.4000/ateliers.9172, accessed 5/07/2017.

DESCLÉS Jean-Pierre and Zlatka GUENTCHÉvA

2010 "Quasi Topological Representation (QTR) of spatial places and spatio-temporal movements in natural Languages", in Giovanna Marotta, Alessandro Lenci, Linda Meini and Francesco Rovai (eds.), Space in Language, Proceedings of the Pisa International Conference, Edizioni ETS, p. 213-233.

2012 "Universals and typology", in Robert Binnick (ed.), Oxford Handbook of Tense and Aspect, New York, Oxford University Press, p. 123-154.

GOSSEN Gary H.

1974 Chamulas in the World of the Sun: Time and Space in a Maya Oral Tradition. Harvard University Press, Cambridge (MA).

HANKS William F.

1984 "Sanctification, structure and experience in a Yucatec Maya ritual event", Journal of American Folklore, p. 131-166.

1990 Referential Practice: Language and Lived Space among the Maya, University of Chicago Press, Chicago, London.

2000 "Copresence and Alterity in Maya Ritual Practice", in William F. Hanks (ed.), Intertexts. Writings and language, utterance and context. Rowman \& Littelfield Publishers, Lanham, Boulder, New York, Oxford. [Originally published as Copresencia y alteridad en la práctica ritual Maya. In 
Manuel León Portilla, Miguel Gutierrez Estevez, Gary Gossen y Jorge Klor de Alva De palabra y obra en el Nuevo Mundo, Siglo XXI de España eds, Madrid, 1993]

2005 "Explorations in the Deictic Field", Current Anthropology, 46 (2), p. 191-220.

2006 "Joint commitment and common ground in a ritual event", in Nick J. Enfield and Stephen C. Levinson, Roots of Human Sociality. Culture, cognition and Interaction, Berg, Oxford, p. 299-328.

LE GUEN Olivier

2017 "Una concepción del tiempo no-lineal en dos lenguas: el maya yucateco colonial y actual y la lengua de señas maya yucateca", Journal de la Société des américanistes, special issue, ("Measures and textures of time among the Mayas") [online]), 2017.

\section{MONOD BECQUELIN Aurore}

2012 “La frontière épaisse. Introduction", Ateliers d'anthropologie [en ligne], 37, http:// ateliers.revues.org/9170, accessed 23/11/2015.

\section{OKOSHI HARADA Tsubasa}

2017 "Entre rutinas cotidianas y eventos extraordinarios: las construcciones de conceptos temporales en la sociedad maya prehispánica", Journal de la Société des américanistes, special issue, ("Measures and textures of time among the Mayas") [on line]), 2017.

\section{RUZ Mario Humberto}

2017 “'Linajes de embustes': cargas de centurias y tiempos universales en el mundo maya colonial”, Journal de la Société des américanistes, special issue, ("Measures and textures of time among the Mayas") [on line]), 2017.

\section{VAPNARSKY Valentina}

1999 Expressions et conceptions du temps chez les Mayas yucatèques, thèse de doctorat, Université Paris 10, Nanterre.

2016 "No Escape from the Future. Temporal Frames and Prediction in Yucatec Maya", in Zlatka. Guentchéva (ed.), Aspectuality and Temporality: Theoretical and Empirical Issues, John Benjamins Publ., Amsterdam, p. 643-678.

2017 "Futuros en contrapunto: proyección, predicción y deseo en maya yucateco/ Futures in counterpoint: Projection, prediction and desire in Yucatec Maya", Journal de la Société des américanistes, special issue, ("Measures and textures of time among the Mayas") [on line]), 2017.

\section{NOTES}

1. The international conference Mesures et textures du temps chez les Mayas/Measures and textures of time among the Mayas was held at the musée du quai Branly, Paris, in October 2014.

2. See also Desclés and Guentchéva (2010). 


\section{ABSTRACTS}

This paper presents an overview of time reckoning in several domains of Maya language and culture, as observed in the Sierra region of Yucatan in the last decades of the twentieth century. It demonstrates that multiple systems of temporal reckoning and orientation co-operate in the traditional domains of daily practice, and it attempts to formulate principles by which different systems are combined in actional frameworks It is argued that most cyclicity in contemporary Yucatec Maya is derivative of natural or social processes and that in rituals it results from the translation of spatial arrays into temporal sequences. The paper tracks the varieties of cyclic and spiral time measurement in several domains, where different units and levels of temporal measurement and different rhythms are observed: 1) the field of co-presence in which utterances are performed, including deictic time; 2) the diurnal cycle and its actional correlates; 3) the agricultural cycles, the forest life cycle and the labor they imply; 4) domestic space whose time involves in addition the age and generational relations among co-residents; 5) ritual time in Yucatec shamanic practice, which is given special attention. Ritual practices display the most dramatic cyclicity, compounded by sedimentation, deictic time, historical time and cosmological space. Their chronometric dimensions are so elaborate that rituals can be considered a time machine. Viewed from practice, there is no single modality of Maya time, but a diachronic synchronization of multiple temporal streams which produces time as the variable product of $t z o l$ reproduction and meyah 'work.'

Este artículo presenta una vista de conjunto de las formas de comput del tiempo en varios dominios de la cultura y de la lengua maya, tal como fueron observadas en la región de la sierra de Yucatán en los últimos decenios del siglo xx. Se demuestra que una multiplicidad de sistemas de cálculo y orientación temporales cooperan en los ámbitos tradicionales de las prácticas cotidianas, y se intenta formular ciertos principios que rigen la combinación de los diferentes sistemas dentro de los marcos de la acción. Se arguye que la mayor parte de las configuraciones cíclicas de los mayas yucatecos contemporáneos puede derivarse de procesos naturales o sociales y que, en el ritual, resulta de la traducción de disposiciones espaciales en secuencias temporales. El autor rastrea la variedad de mediciones del tiempo en varios dominios, para los cuales se observa una diversidad tanto de unidades y niveles de medida temporal como de ritmos: 1) el campo de co-presencia en el cual ocurren las enunciaciones, incluyendo el tiempo deíctico; 2) el ciclo diurno y sus correlatos accionales ; 3) los ciclos agrícolas y silvestres, y las labores que implican ; 4) el espacio doméstico que supone además la edad y las relaciones intergeneracionales entre coresidentes. 5) el tiempo ritual en las prácticas chamanicas yucatecas, al cual se presta mayor atención. Éstas prácticas manifiestan la forma de ciclicidad más dramática, compuesta por sedimentación, tiempo deíctico, tiempo cíclico y espacio cosmológico. Sus dimensiones cronométricas son tan elaboradas que los rituales pueden ser considerados como máquinas del tiempo. Del punto de vista de las prácticas, no existe una modalidad del tiempo maya única, sino una sincronización diacrónica de corrientes temporales múltiples que hacen del tiempo un producto variable del ordenamiento 'tzol' y del trabajo 'meyah'.

Cet article présente une vue d'ensemble des formes de comput du temps dans plusieurs domaines de la culture et de la langue maya, telle qu'observée dans la région centrale du Yucatán durant 
les dernières décennies $\mathrm{du} \mathrm{xx}^{\mathrm{e}}$ siècle. Il s'attache à démontrer qu'une multiplicité de systèmes de calcul et d'orientation temporels sont conjointement à l'œuvre dans les domaines traditionnels des pratiques quotidiennes. Il tente de formuler certains des principes qui régissent la combinaison des différents systèmes au sein de cadres actionnels. L'auteur argumente que la plupart des configurations cycliques des Mayas yucatèques contemporains sont dérivées de processus naturels ou sociaux et que, dans le rituel, elles résultent de la traduction de dispositions spatiales dans des séquences temporelles. Il recherche la variété des mesures du temps dans plusieurs domaines, où on observe une diversité tant d'unités et niveaux de mesure temporelle que de rythmes: 1) le champ de co-présence au sein duquel prennent place les énonciations, incluant le temps déictique ; 2) le cycle diurne et ses corrélats actionnels ; 3) les cycles agricoles et sylvestres et les tâches qu'ils impliquent ; 4) l'espace domestique pour lequel s'ajoutent l'âge et les relations intergénérationnelles entre co-résidents ; 5) le temps rituel dans les pratiques chamaniques yucatèques, auquel il est porté une particulière attention. Ces pratiques manifestent la forme de cyclicité la plus dramatique, composée par sédimentation de temps déictique, temps historique et espace cosmologique. Leurs dimensions chronométriques sont si élaborées que les rituels peuvent être considérés comme des machines à voyager dans le temps. Du point de vue des pratiques, il n'y a pas une simple modalité du temps maya, mais plutôt une synchronisation diachronique de courants temporels multiples qui fait du temps une variable soumise à l'ordonnancement 'tzol' et au travail 'meyah'.

INDEX

Palabras claves: enunciación, indexical, tiempo cíclico, sincronía, ritual chamanico, maya Mots-clés: énonciation, indexical, temps cyclique, synchronie, rituel chamanique, Maya

Keywords: phenomenal field of utterance, cyclic time, synchrony, shamanic ritual, Maya

\section{AUTHOR}

\section{WILLIAM F. HANKS}

University of California, Berkeley, USA - [wfhanks@berkeley.edu] 